\title{
PENERAPAN LESSON STUDY DALAM PERKULIAHAN MATEMATIKA DASAR PADA MAHASISWA PENDIDIKAN BIOLOGI UNIVERSITAS PASIR PENGARAIAN
}

\section{IMPLEMENTATION OF LESSON STUDY IN BASIC MATHEMATICS LECTURE ON BIOLOGY EDUCATION STUDENTS OF PASIR PENGARAIAN UNIVERSITY}

\author{
Ratri Isharyadi ${ }^{1}$, Lusi Eka Afri ${ }^{2}$, Annajmi ${ }^{3}$ \\ 1,2,3 Universitas Pasir Pengaraian, Jl.Tuanku Tambusai Kumu Rambah Hilir Pasir \\ Pengaraian \\ Kabupaten Rokan Hulu, Riau
}

\begin{abstract}
ABSTRAK
Lesson study merupakan cara yang bisa dilakukan dosen untuk mengetahui kesulitan yang dialami mahasiswa dalam perkuliahan, hasil pengamatan dapat digunakan sebagai masukan dalam memperbaiki proses perkuliahan dan memotivasi dosen untuk selalu melakukan perubahan guna menjadi dosen yang profesional. Penelitian ini dilaksanakan di Program Studi Pendidikan Biologi Universitas Pasir Pengaraian, dengan subjek penelitian adalah mahasiswa S-1 yang mengambil mata kuliah matematika dasar tahun akademik 2019/2020 semester ganjil yang berjumlah 28 orang. Penelitian ini merupakan penelitian deskriptif kualitatif. Pelaksanaan penelitian menggunakan tahapan plan, do dan see. Instrument penelitian berupa lembar observasi, rekaman video dan hasil pekerjaan mahasiswa berupa lembar kerja mahasiswa. Data hasil observasi dianalisis secara deskriptif, data hasil belajar matematis peserta didik dianalisis untuk mengetahui proses pembelajaran matematika dasar melalui lesson study. Pelaksanaan Lesson study di perkuliahan matematika dasar secara garis besar berjalan dengan baik. Pelaksanaan pembelajaran berjalan sesuai dengan yang direncanakan. Selama proses pembelajaran, mahasiswa terlibat aktif dalam mempelajari materi perkuliahan. Adapun pentingnya dilakukan penelitian ini yaitu untuk mengetahui kesulitan belajar yang dialami mahasiswa serta mewujudkan perkuliahan matematika dasar menjadi lebih baik melalui proses-proses kolaborasi yang dilakukan oleh tim peneliti, melalui masukan-masukan dan refleksi yang telah dilakukan.
\end{abstract}

Kata Kunci : lesson study, kolaborasi, matematika dasar, deskriptif kualitatif

\begin{abstract}
Lesson study is a way that lecturers can do to find out the difficulties experienced by students in lectures, and observations can be used as input in improving the lecture process and motivate lecturers always to make changes become professional lecturers. This research was carried out in the Biology Education Study Program at the Pasir Pengaraian University, with the subject of the study being undergraduate students taking basic mathematics courses in the 2019/2020 academic year odd semester totaling 28 people. This research is a qualitative descriptive study. The research uses the stages of plan, do and see. The research instrument in the form of observation sheets, video recordings and the results of student work in the form of student worksheets. Observation data were analyzed descriptively, students' mathematical learning outcomes data were analyzed to find out the basic mathematics learning process through lesson study. The implementation of Lesson study in
\end{abstract}


basic mathematics courses, in general, went well. The implementation of learning runs as planned. During the learning process, students are actively involved in the learning lecture material. The importance of this research is to find out the learning difficulties experienced by students and to realize basic mathematics lectures to be better through the collaborative processes carried out by the research team, through the input and reflection that has been done.

Keywords: lesson study, collaboration, basic mathematics, qualitative descriptive

How to Cite: Isharyadi, R., Afri, L. E., \&Annajmi. (2020). Penerapan Lesson Study dalam Perkuliahan Matematika Dasar pada Mahasiswa Pendidikan Biologi Univeritas Pasir Pengaraian. Mathline: Jurnal Matematika dan Pendidikan Matematikan, Vol.5, No.1, 47-60

DOI: https://doi.org/10.31943/mathline.v5i1.131

\section{PENDAHULUAN}

Kompetensi yang harus dimiliki oleh seorang guru menurut UU Nomor 14 Tahun 2005 yaitu kompetensi pedagogik, kepribadian, profesional, dan sosial. Seperti halnya guru, dosen juga merupakan seorang pendidik yang seharusnya juga memiliki keempat kompetensi tersebut. Banyak hal yang dapat dilakukan sebagai upaya untuk meningkatkan kompetensi tersebut. Salah satu pendekatan yang dapat menjadi pusat pengembangan pedagogi dengan menyelidiki pembelajaran mahasiswa adalah penggunaan lesson study (Wood, 2016). Kompetensi pedagogi merupakan kemampuan pemahaman terhadap peserta didik, perancangan dan pelaksanaan pembelajaran, evaluasi hasil belajar, dan pengembangan peserta didik untuk mengaktualisasikan berbagai potensi yang dimilikinya. Dalam kompetensi profesional, Ario (2019) menyatakan bahwa melalui lesson study, sekelompok pendidik dapat saling berbagi pengalaman tentang materi pelajaran. Kompetensi profesional adalah penguasaan materi pembelajaran secara luas dan mendalam, yang mencakup penguasaan materi kurikulum dan substansi keilmuan yang menaungi materinya, serta penguasaan terhadap struktur dan metodologi keilmuannya.

Penggunaan lesson study dalam konteks universitas/perguruan tinggi sudah populer di beberapa negara, seperti Australia, AS, Denmark, Cina, dan lain-lain. (Wood, 2016). Lesson study adalah istilah umum yang digunakan untuk siklus kolaboratif di mana pendidik meneliti kurikulum dan perangkat pembelajaran, rencana pelaksanaan pembelajaran, dan mengamati, mendiskusikan dan merenungkan pelaksanaan pembelajaran, menggunakan data yang dikumpulkan selama observasi untuk menarik implikasi dari proses pembelajaran 
(Lewis 2016). Lesson study merupakan pendekatan pengembangan profesional yang berpusat pada kolaborasi. Ini bukan hal yang luar biasa, dan hal ini bukan merupakan sesuatu yang menjadikan lesson study unik (Bjuland, 2015). Menurut Murata, ide sederhana lesson study adalah guru secara alami datang bersama dengan pertanyaan bersama mengenai pembelajaran murid di kelas mereka, merencanakan pelajaran untuk membuat pembelajaran dengan siswa dapat diamati, dan memeriksa serta membahas apa yang mereka amati. Melalui beberapa literasi proses, guru memiliki banyak kesempatan untuk membahas pembelajaran siswa dan bagaimana pengajaran mereka mempengaruhinya (Bjuland, 2015). Lesson study merupakan satu cara yang efektif untuk meningkatkan kualitas proses pembelajaran. Hal ini didasarkan karena pengembangan lesson study dilakukan pada hasil sharing pengetahuan profesional yang berlandaskan pada praktik dan hasil pembelajaran yang dilakukan oleh dosen.

Santyasa (Vitantri, 2014) menjelaskan bahwa lesson study menyediakan suatu proses untuk berkolaborasi, merancang pembelajaran, dan mengevaluasi kesuksesan strategistrategi mengajar yang telah diterapkan sebagai upaya meningkatkan proses serta perolehan belajar siswa. Penekanan yang mendasar dari lesson study adalah agar para mahasiswa memiliki kualitas belajar yang tinggi. Dengan demikian, kualitas pembelajaran mahasiswa dapat meningkat (Mahendra, 2016).

Gagasan kunci tertentu membedakan lesson study dengan pendekatan lain untuk pengembangan profesional (Bjuland, 2015), yaitu:

1. Pembelajaran siswa adalah fokus dalam lesson study. Sepanjang siklus pembelajaran, guru mengidentifikasi tujuan siswa dalam mempelajari suatu topik, menyelidiki materi kurikulum yang mengajarkan topik, merencanakan pelajaran yang membuat pembelajaran siswa di kelas dengan topik tertentu dapat diamati, mengumpulkan data dari proses pembelajaran, setelah itu, mendiskusikan pembelajaran yang telah dilakukan.

2. Terkait dengan poin pertama, observasi sangat penting dalam lesson study. Karena pembelajaran direncanakan untuk membuat prosesnya dapat diamati, semua peserta dalam kelompok lesson study (dosen) memfokuskan perhatian mereka pada mengamati pembelajaran siswa. Fokus pada observasi juga berkaitan dengan perumusan dan mengejar pertanyaan penelitian untuk siklus pembelajaran, karena pedoman untuk observasi perlu diambil dari pertanyaan penelitian yang menyediakan isian untuk mengidentifikasi dan mengumpulkan bukti dari pengamatan. 
3. Ketiga, pelajaran penelitian adalah unit analisis dalam lesson study. Merujuk pada hal tersebut, mengindikasikan bahwa pelajaran tersebut bertujuan untuk menyelidiki masalah tertentu yang terkait dengan pembelajaran para pendidik yang ikut berpartisipasi dalam lesson study. Saat menerapkan pelajaran di negara lain, aspek ini cenderung menghilang, dan Fujii (2014) menyebutnya sebagai kesalahpahaman umum tentang lesson study.

Hasil penelitian (Wood, 2016) menunjukkan bahwa lesson study memiliki potensi sebagai kendaraan yang unggul mengembangkan praktik reflektif dosen. Diskusi yang dilakukan dengan mahasiswa memberikan sejumlah wawasan baru ke dalam pekerjaan sebagai praktisi dan peneliti. Diskusi tentang proses pembelajaran itu sendiri, dan khususnya berbagai pendekatan pedagogi yang menurut mahasiswa berharga, telah sangat menambah pemahaman sebagai dosen. Hasil penelitian Obara (2019) menyatakan bahwa menggunakan lesson study untuk pengembangan profesional memiliki potensi besar untuk meningkatkan kualitas pembelajaran. Pada prinsipnya, lesson study masih menawarkan para pendidik kesempatan untuk merefleksikan secara kolaboratif pada penerapan pembelajaran mereka. Tujuan utama dari lesson study adalah untuk memberi kesempatan bagi pendidik untuk meningkatkan kemampuan mengajar mereka.

Beberapa kegiatan yang dilakukan pendidik dalam lesson study (Lewis, 2016) adalah:

a. Mempelajari isi dan materi pengajaran dan mempertimbangkan tujuan jangka panjang bagi mahasiswa;

b. Merencanakan pelajaran penelitian yang menghidupkan tujuan mereka dan ide tentang pembelajaran yang berkualitas;

c. Dengan cermat mengamati pelajaran dan mencatatkan langsung tanggapan siswa terhadap proses pembelajaran;

d. Berbagi, menganalisis, dan mendiskusikan data yang dikumpulkan selama pembelajaran;

e. Berinteraksi dengan pendidik lain (seringkali termasuk konten ahli eksternal) dan memahami ide mereka tentang konten, pengajaran, dan pembelajaran.

Salah satu mata kuliah yang masih dianggap sulit oleh mahasiswa Pendidikan Biologi Universitas Pasir Pengaraian adalah mata kuliah matematika dasar atau kalkulus. Mata kuliah ini merupakan mata kuliah wajib program studi yang sudah seharusnya mendapat perhatian bagi dosen pengampu, agar mendapat masukan dari rekan sejawat demi perbaikan proses pembelajaran yang nantinya akan berimplikasi pada hasil pembelajaran. Materi utama pada matematika dasar dan yang akan menjadi fokus pada penelitian ini adalah fungsi dan limit. 
Hendayana (Vitantri, 2014) mengungkapkan bahwa lesson study merupakan suatu model pembinaan profesi pendidikan melalui pengkajian pembelajaran secara kolaboratif dan berkelanjutan berlandaskan prinsip kolegalitas dan mutual learning untuk membangun komunitas belajar. Hal ini sebagaimana yang diungkapkan oleh Murwaningsih dan Wulandari (2011) bahwa lesson study merupakan pendekatan yang komprehensif menuju pembelajaran yang profesional serta menopang dosen menjadi pembelajar sepanjang hayat dalam upaya mengembangkan dan meningkatkan kualitas pembelajaran di kelas.

Dengan penerapan lesson study, diharapkan pembelajaran matematika dasar menjadi lebih baik melalui proses-proses kolaborasi yang dilakukan oleh tim peneliti, melalui masukan-masukan dan refleksi pembelajaran yang telah dilakukan. Oleh karena itu, dilaksanakan penelitian dengan penerapan lesson study pada pembelajaran matematika dasar bagi mahasiswa Pendidikan Biologi Universitas Pasir Pengaraian. Berkaitan dengan uraian permasalahan yang telah diuraikan, maka tujuan dari penelitian ini adalah untuk mendeskripsikan pelaksanaan pembelajaran melalui lesson study di Program Studi Pendidikan Biologi pada mata kuliah matematika dasar.

\section{METODE PENELITIAN}

Penelitian ini merupakan penelitian deskriptif kualitatif. Prosedur pelaksanaannya menggunakan metode pengembangan sistem pembelajaran yaitu kegiatan lesson study. Penelitian dilaksanakan di Program Studi Pendidikan Biologi Universitas Pasir Pengaraian. Pelaksanaan penelitian ini pada perkuliahan semester ganjil tahun akademik 2019/2020 yang berjumlah 28 orang. Tahapan dalam lesson study meliputi (1) Perencanaan (Plan), (2) Pelaksanaan (Do), dan (3) Refleksi (See). Secara umum Abizar (2017) menguraikan setiap tahapan lesson study sebagai berikut.

\section{Perencanaan (Plan)}

Pada tahap perencanaan ini, para dosen yang tergabung dalam tim lesson study berkolaborasi menyusun rencana pembelajaran untuk tercapainya tujuan pembelajaran. Perencanaan diawali dengan kegiatan menganalisis kebutuhan dan permasalahan yang dihadapi mahasiswa dalam pembelajaran. Analisis mencakup kesulitan yang dihadapi siswa, kompetensi dasar yang harus diajarkan, materi, cara membelajarkan siswa, dan sebagainya. Hasil analisis ini menjadi bagian yang dipertimbangkan dalam menyusun RPS, lembar aktivitas mahasiswa (LAM), media pembelajaran, strategi pembelajaran, dan lembar penilaian dalam hal ini lembar observasi untuk mengamati aktivitas belajar mahasiswa. 
2. Pelaksanaan $(D o)$

Pada tahap pelaksanaan, terdapat dua kegiatan utama, yaitu (1) kegiatan pelaksanaan pembelajaran yang dilakukan oleh salah seorang dosen yang telah disepakati menjadi dosen model untuk mempraktikan RPS yang sudah disusun bersama tim lesson study, dan (2) kegiatan pengamatan atau observasi yang dilakukan oleh tim lesson study yang lain.

\section{Refleksi (See)}

Pada tahap refleksi, dilakukan dalam bentuk diskusi yang diikuti semua anggota tim lesson study dengan upaya perbaikan proses pembelajaran berikutnya. Ketajaman analisis tim Lesson study sangat penting pada tahap ini. Kegiatan refleksi dipandu oleh salah seorang dari tim yang sudah ditunjuk. Diskusi dimulai dari penyampaian kesan-kesan dosen model yang sudah mempraktikkan pembelajaran baik kelebihan maupun kekurangan dalam melaksanakan tugasnya. Selanjutnya, semua observer menyampaikan tanggapan terkait proses pembelajaran yang telah dilaksanakan sesuai fakta yang diperoleh di lapangan.

Pengumpulan data dilakukan dengan dengan teknik tes dan non tes. Teknik tes dilakukan melalui tournament menggunakan aplikasi kahoot untuk memperoleh data hasil belajar matematika mahasiswa. Teknik non tes, yaitu observasi, diskusi, dan dokumentasi berupa video dilakukan untuk memperoleh data kegiatan proses pembelajaran. Instrumen yang digunakan dalam kegiatan lesson study meliputi instrumen tes dan dan non tes. Instrumen tes berupa soal tournament menggunakan aplikasi kahoot. Instrumen non tes berupa lembar observasi. Lembar observasi disajikan dalam bentuk pertanyaan-pertanyaan tentang kegiatan pembelajaran dan dilengkapi catatan penting untuk temuan dalam proses pembelajaran. Data hasil belajar matematis mahasiswa dianalisis untuk mengetahui hasil belajar matematika mahasiswa. Data kegiatan proses pembelajaran yang diperoleh dianalisis secara deskriptif yaitu mendeskripsikan proses pembelajaran yang dirangkum dari hasil pengamatan observer, dokumentasi, dan hasil diskusi tim.

\section{HASIL DAN PEMBAHASAN}

\section{Hasil Penelitian}


Penelitian ini dilaksanakan sesuai dengan tahapan dalam pelaksanaan kegiatan pembelajaran lesson study, meliputi (1) Perencanaan (Plan), (2) Pelaksanaan (Do), dan (3) Refleksi (See). Adapun pelaksanaan dari pembelajaran dapat dideskripsikan sebagai berikut.

\section{Tahap Perencanaan (Plan)}

Perencanaan pembelajaran lesson study diawali dengan kegiatan diskusi tim lesson study terkait rancangan pelaksanaan kegiatan. Rancangan ini meliputi mekanisme dan teknis pelaksanaan kegiatan lesson study, tujuan lesson study, sasaran dari kegiatan lesson study dan waktu pelaksanaan kegiatan lesson study. Semua anggota tim berkolaborasi dalam menyusun rancangan.



Gambar 1. Pelaksanaan Tahap Plan

Berdasarkan hasil diskusi terkait penentuan dosen model yang berperan menyampaikan pembelajaran, yaitu dosen yang mengampu mata kuliah matematika dasar pada Program Studi Pendidikan Biologi FKIP UPP yaitu Bapak Ratri Isharyadi, M.Pd. Pembentukan kelompok dilakukan oleh dosen model yaitu ada sebanyak 7 kelompok dan masing-masing kelompok terdiri dari 4 hingga 5 orang mahasiswa.

Dosen model dan tim lesson study berdiskusi untuk mengidentifikasi materi yang akan diajarkan kepada mahasiswa. Bahan kajian yang akan digunakan adalah materi relasi dan fungsi dengan sub materi konsep relasi, definisi fungsi, menyatakan fungsi dan domain dan range suatu fungsi. Selanjutnya, dilakukan penyiapan perangkat pembelajaran yaitu Rencana Pembelajaran Semester (RPS), Lembar Aktivitas Mahasiswa (LAM), video pembelajaran, soal kuis, dan soal turnamen disesuaikan dengan Capaian Pembelajaran Mata Kuliah 
(CPMK) serta sub CPMK, serta bahan kajian materi. Perangkat pembelajaran disiapkan oleh tim sesuai dengan pembagian tugas yang sudah ditetapkan. LAM dan video pembelajaran berguna untuk meningkatkan keaktifan mahasiswa dalam mengikuti perkuliahan. Kedua perangkat ini sangat membantu mahasiswa untuk dapat memahami materi yang dibahas pada perkuliahan. Tahap berikutnya menentukan waktu pelaksanaan kegiatan dan disepakati pada hari Kamis tanggal 14 November 2019 pukul 13.30 s.d. 15.45 WIB.

\section{Tahap Pelaksanaan (Do)}

Tahap Do merupakan penerapan rencana pembelajaran dengan menggunakan perangkat pembelajaran yang sudah disusun oleh tim. Tahap ini dilakukan sesuai dengan jadwal yang sudah ditetapkan tim pada tahap perencanaan. Pada tahap ini, dosen model mengajar dengan pengamatan para observer. Kegiatan pembelajaran dimulai dengan menonton video pembelajaran materi relasi dan fungsi yang telah dibagikan kepada seluruh mahasiswa seminggu sebelum pertemuan. Seluruh mahasiswa ditugaskan untuk mempelajari materi yang disajikan pada video tersebut.

Pada awal pertemuan dosen model mengkonfirmasi terkait video yang sudah ditonton oleh mahasiswa. Selanjutnya selama kurang lebih sepuluh menit, dosen memberikan soal kuis sebanyak dua soal kepada mahasiswa. setelah waktunya habis, maka semua lembar jawaban mahasiswa dikumpulkan dan dosen model memeriksa jawaban kuis secara umum.

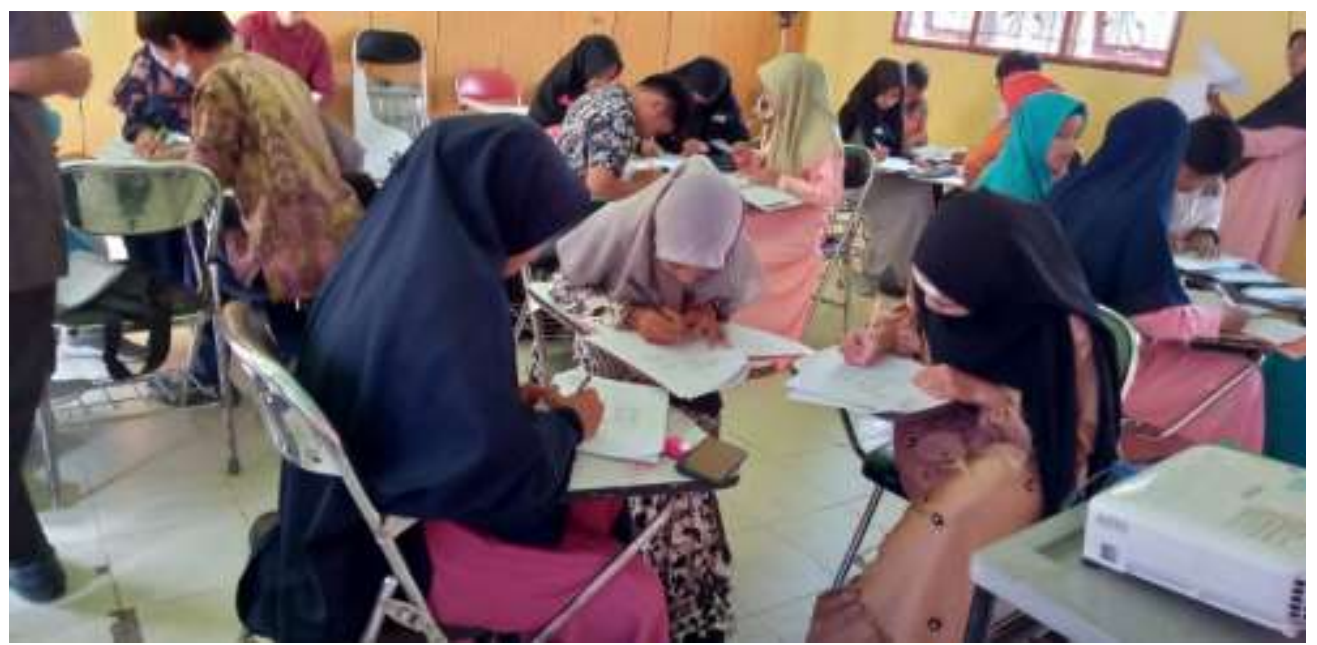

Gambar 2. Kuis Individu

Selanjutnya, dosen model mengarahkan kepada seluruh mahasiswa untuk duduk pada kelompok masing-masing yang sudah dibagi sebelumnya. Mahasiswa dikelompokkan menjadi tujuh kelompok secara heterogen. Dosen membagikan nomor punggung dan LAM 
kepada setiap mahasiswa. LAM yang terdiri dari Sembilan pertanyaan didiskusikan bersama selama 50 menit dalam kelompok masing-masing.

Dosen model memegang kendali selama proses pembelajaran dan di saat yang bersamaan observer melakukan observasi keterlaksanaan pembelajaran. Observer yang hadir berjumlah enam orang dosen pendidikan matematika FKIP UPP yaitu Ibu Lusi Eka Afri, M. Si, Ibu Hera Deswita, M. Pd, Ibu Riska Novia Sari, M. Pd, Bapak Marfi Ario, M. Pd, Bapak Arcat, M. Pd, dan Bapak Annajmi, M.Pd.

Dalam proses diskusi LAM, dosen model berkeliling ke setiap kelompok untuk melihat perkembangan diskusi yang dilakukan mahasiswa. Hampir semua kelompok memiliki kesulitan dalam mengerjakan LAM. Dosen model berusaha mengarahkan mahasiswa untuk dapat memahami materi sesuai LAM.

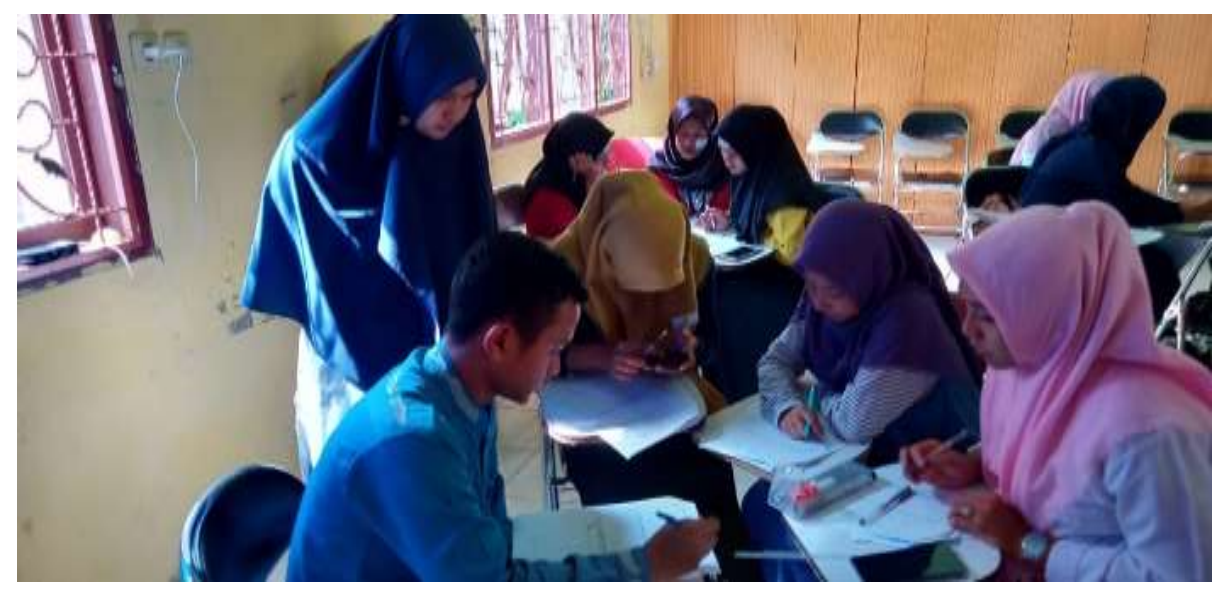

Gambar 3. Proses Pembelajaran dan Observasi

Pada akhir pembelajaran dilakukan turnamen dengan menggunakan aplikasi kahoot. Hal ini dilakukan untuk memotivasi mahasiswa tetap semangat dan sekaligus untuk melihat hasil belajar mahasiswa terhadap pembelajaran yang telah dilaksanakan. Aturan turnamen adalah setiap kelompok mengirim satu orang utusannya secara bergantian untuk bermain. Soal yang disediakan ada sebanyak delapan soal dimana setiap mahasiswa akan bermain sebanyak dua kali. 


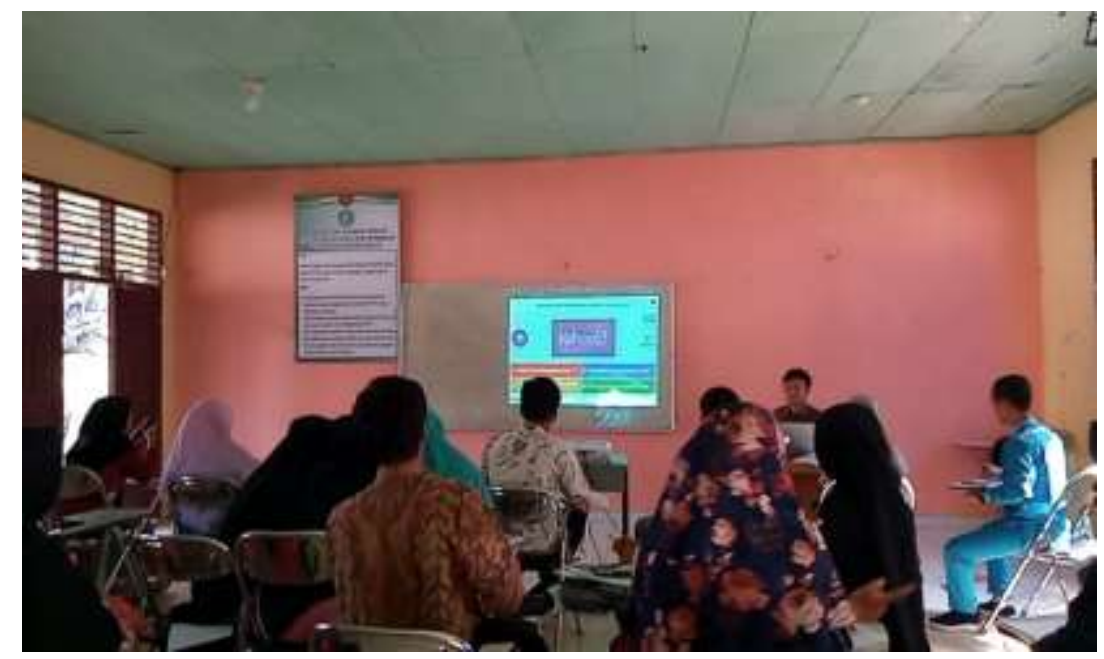

Gambar 3. Suasana Kuis dengan Lesson study

Mahasiswa sangat antusias mengikuti turnamen yang disajikan dengan menggunakan aplikasi kahoot. Keberhasilan dalam menjawab dengan cepat dan benar membuat mahasiswa semakin termotivasi dan bahkan berharap diadakan lagi turnamen untuk pertemuan selanjutnya. Selesai pelaksanaan turnamen dosen model mengumumkan tim yang menjadi pemenang. Proses pembelajaran ditutup oleh dosen model. Hasilnya disajikan pada tabel 1 berikut.

Tabel 1. Hasil Tournament Materi Relasi dan Fungsi

\begin{tabular}{ccccc}
\hline Rangking & $\begin{array}{c}\text { Nama } \\
\text { Kelompok }\end{array}$ & $\begin{array}{c}\text { Total } \\
\text { skor }\end{array}$ & $\begin{array}{c}\text { Jawaban } \\
\text { benar }\end{array}$ & $\begin{array}{c}\text { Jawaban } \\
\text { salah }\end{array}$ \\
\hline 1 & A & 4889 & 6 & 2 \\
\hline 2 & B & 3678 & 4 & 4 \\
\hline 3 & C & 3222 & 4 & 4 \\
\hline 4 & D & 3101 & 4 & 4 \\
\hline 5 & E & 3066 & 4 & 4 \\
\hline 6 & F & 2633 & 3 & 5 \\
\hline 7 & G & 2323 & 3 & 5 \\
\hline
\end{tabular}

Berdasarkan tabel 1 terlihat bahwa skor yang diperoleh oleh masing-masing kelompok diurutkan menurut rangking teratas. Kelompok " $\mathrm{A}$ ” mendapat skor tertinggi yaitu 4889 dengan 6 (enam) jawaban benar dari 8 (delapan) soal yang diberikan.

\section{Tahap Refleksi (See)}

Refleksi pembelajaran dilakukan sesaat setelah pembelajaran dilakukan di suatu ruang tersendiri. Tahap ini dilakukan dalam bentuk diskusi grup dengan para observer. Halhal yang didiskusikan pada tahap ini terkait proses pembelajaran yang telah berlangsung. 
Kegiatan refleksi dipimpin oleh seorang moderator dan dibantu oleh sekretaris. Kegiatan diawali dengan pandangan dosen model terkait pembelajaran yang telah dilaksanakannya. Kemudian dilanjutkan dengan komentar dan saran dari observer. Selanjutnya dosen model diminta memberikan tanggapan kembali terhadap komentar yang diberikan oleh observer. Adapun beberapa pandangan dan komentar serta saran pada tahap refleksi diantaranya: (1) beberapa mahasiswa belum memahami materi yang ada di video, sehingga masih kesulitan mengerjakan LAM yang diberikan. Ada kemungkinan mahasiswa belum menonton video dengan tuntas, hal ini disebabkan karena durasi video terlalu panjang yaitu 28 menit. Jadi, diharapkan pada video selanjutnya durasi waktu lebih diperpendek lagi, (2) masih terdapat mahasiswa yang individual dalam kelompok sehingga diskusi kelompok belum berjalan sepenuhnya, (3) mahasiswa sangat antusias dalam melaksanakan turnamen, (4) perlunya penyajian konsep secara klasikal apabila banyak mahasiswa yang mengalami kesulitan, dan (5) pembagian waktu pada kegiatan diskusi dan turnamen sudah baik.

\section{Pembahasan}

Pelaksanaan lesson study pada perkuliahan Matematika Dasar berjalan dengan baik. Hasil tes tertulis yang dilaksanakan melalui turnamen kelompok menunjukkan bahwa masih terdapat 2 kelompok dengan persentase pencapaian di bawah 50\%. Selanjutnya, proses pembelajaran juga berjalan dengan baik. Hal ini diperoleh dari hasil observasi para observer yang menunjukkan bahwa sebagaian besar mahasiswa mengikuti pelajaran dengan baik dan terlibat aktif dalam perkuliahan. Hal ini sejalan dengan hasil penelitian Sapawardi (2015) bahwa penerapan lesson study pada mata kuliah kalkulus integral selain dapat meningkatkan kualitas proses pembelajaran juga meningkatkan hasil belajar mahasiswa. Selanjutnya, hasil penelitian Ario (2019) menunjukkan bahwa lesson study dapat meningkatkan keaktifan mahasiswa dalam perkuliahan.

Keberhasilan dalam proses dan hasil belajar tersebut merupakan dampak dari rancangan kegiatan pembelajaran yang dilaksanakan. Secara umum kegiatan pembelajaran berlangsung melalui beberapa tahapan. Tahapan pertama mahasiswa diminta untuk menonton materi perkuliahan dalam bentuk video melalui youtube. Hal ini merupakan metode pembelajaran yang efektif bagi mahasiswa untuk memahami materi perkuliahan. Mahasiswa akan lebih cepat memahami dan mengingat materi dalam bentuk visual. Materi yang mereka tonton adalah materi relasi dan fungsi. Materi pelajaran ini dibuat sendiri oleh dosen model. Setelah itu mereka masuk dikelas dan mengikuti kuis. Kuis dilakukan secara 
tertulis untuk menguji pemahaman mahasiswa dari video pembelajaran yang telah mereka tonton. Selanjutnya dosen memberikan arahan untuk mahasiswa mengerjakan beberapa soal latihan melalui Lembar Aktivitas Mahasiswa (LAM). Selama mahasiswa mengerjakan LAM, dosen aktif memberikan bimbingan kepada setiap kelompok. Pada akhir perkuliahan, diadakan turnamen untuk mengukur ketercapaian tujuan pembelajaran. Turnamen yang diberikan dengan menggunakan aplikasi kahoot. Aplikasi ini mengukur tingkat ketepatan dan kecepatan dalam menjawab.

Proses pembelajaran seperti yang telah dijelaskan tersebut berhasil dalam meningkatkan proses dan hasil belajar mahasiswa. Video pembelajaran yang diberikan sebelum perkuliahan bertujuan untuk memfasilitasi mahasiswa dalam memahami materi perkuliahan yang akan dipelajari pada pertemuan berikutnya. Ketika mahasiswa masuk ke kelas untuk memulai pembelajaran, mereka telah memiliki kemampuan awal tentang materi yang ingin dipelajari. Berdasarkan hasil tanya jawab dosen dengan mahasiswa di awal perkuliahan diperoleh informasi bahwa seluruh mahasiswa telah menonton video pembelajaran yang diberikan. Kuis pada awal pembelajaran ini berfungsi untuk mendorong mahasiswa agar menonton video pembelajaran sebelum masuk perkuliahan. Dengan adanya kuis, maka mahasiswa merasa khawatir tidak bisa menjawabnya. Agar mereka bisa menjawab kuis, maka mereka harus menonton video pembelajaran terlebih dahulu. Berdasarkan hasil kuis terlihat bahwa sebagian besar mahasiswa menonton video pembelajaran dan memahami materi perkuliahan yang disajikan di dalamnya.

Kegiatan diskusi kelompok dimaksudkan untuk mahasiswa berlatih dalam mengerjakan soal-soal latihan tentang relasi dan fungsi yang disajikan dalam LAM. Diskusi juga dimaksudkan agar mahasiswa berdiskusi dan saling membantu memahami materi dan mengerjakan soal-soal latihan. Keaktifan, kemandirian dan pemahaman mahasiswa terlihat dalam memahami materi. Kemandirian dan pemahaman mahasiswa dalam memahami materi melalui video yang sudah dibagikan terlihat dari keaktifan mahasiswa dalam berdiskusi dan berbagi dengan teman dalam kelompok.

Turnamen dengan menggunakan aplikasi kahoot, pada akhir perkuliahan sebagai evaluasi dari ketercapaian tujuan pembelajaran. Dosen menjelaskan bahwa pada saat turnamen, masing-masing anggota kelompok akan maju mewakili kelompoknya. Nilai kelompok merupakan akumulasi dari nilai setiap anggotanya. Dengan sistem seperti ini maka mahasiswa berusaha untuk membuat setiap anggota kelompoknya dapat memahami materi agar mampu menjawab soal turnamen. Keberhasilan dalam menjawab dengan cepat dan 
benar membuat mahasiswa semakin termotivasi dan bahkan berharap diadakan lagi turnamen untuk pertemuan selanjutnya. Selesai pelaksanaan turnamen dosen model mengumumkan tim yang menjadi pemenang.

Berdasarkan hasil diskusi pada tahap refleksi ditemukan bahwa adanya integrasi teknologi dalam pembelajaran dimana mahasiswa sudah dibiasakan untuk belajar mandiri dan aktif dengan menggunakan video pembelajaran serta turnamen dengan aplikasi kahoot yang berbasiskan kepada ketepatan dan kecepatan. Selain itu, Lembar Aktivitas Mahasiswa tidak hanya sebatas pada mengarahkan mahasiswa untuk memahami materi yang dipelajari tetapi juga mengajak mahasiswa untuk belajar secara aktif dan mandiri. Pembelajaran berbasis video ini memfasilitasi mahasiswa untuk mempertahan pengetahuan dan mengingatnya lebih tepat. Karena pada dasarnya, manusia memiliki kemampuan untuk memroses gambar 60.000 kali lebih cepat daripada teks biasa. Pembelajaran berbasis video lebih efektif. Video yang lebih menarik akan mempermudah dan memotivasi mahasiswa untuk dapat memahami materi.

Rangkaian kegiatan pembelajaran tersebut ternyata dapat meningkatkan kualitas proses pembelajaran dan juga pemahaman mahasiswa dalam memahami materi perkuliahan. Walaupun demikian, masih terdapat beberapa perbaikan yang harus dilakukan untuk kedepannya.

\section{KESIMPULAN}

Pelaksanaan Lesson study di perkuliahan Matematika Dasar secara garis besar berjalan dengan baik. Pelaksanaan pembelajaran berjalan sesuai dengan yang direncanakan. Selama proses pembelajaran, mahasiswa terlibat aktif dalam mempelajari materi perkuliahan. Pembelajaran yang dilaksanakan dalam penelitian ini berbasis video dan evaluasi pembelajaran berbasis turnamen yang terintegrasi teknologi. Hasil belajar yang diperoleh dari turnamen di akhir pelajaran menunjukkan tercapainya tujuan pembelajaran. Pelaksanaan lesson study dapat memberikan wadah untuk para pendidik saling berbagi pengalaman tentang praktik terbaik dalam pembelajaran. Kolaborasi antar dosen dalam mempersiapkan dan melaksanakan pembelajaran memberikan hasil yang baik dalam proses dan hasil belajar mahasiswa. Adapun video materi relasi dan fungsi dapat diakses pada tautan berikut https://www.youtube.com/watch?v=g3BWMq0S6gA. 


\section{REFERENSI}

Abizar, H. 2017. Buku Master Lesson study. Yogyakarta: Diva Press

Ario, M. (2019). Implementasi Lesson study Untuk Menumbuhkan Keaktifan Belajar Dan Kerjasama Mahasiswa. Absis, 1 No 2(April 2019), 1-11.

Bjuland, R., \& Mosvold, R. (2015). Lesson study in teacher education : Learning from a challenging case. Teaching and Teacher Education, 52, 83-90. https://doi.org/10.1016/j.tate.2015.09.005

Fujii, T. (2014) Implementing Japanese Lesson Study in Foreign Countries: Misconceptions Revealed. Mathematics Teachers Education and Development 16(1), n1, 2014. Dapat diakses di eric.ed.gov

Lewis, C. (2016). How does lesson study improve mathematics instruction? ZDM. https://doi.org/10.1007/s11858-016-0792-X

Mahendra, I. W. E. (2016). Pendekatan Pembelajaran Kontekstual Setting Lesson study dalam Mata Kuliah Kalkulus. Emasains : Jurnal Edukasi Matematika Dan Sains, 5 No 2 (September 2016), 25-30.

Murwaningsih, U dan Wulandari, A.A. (2011). Penerapan Lesson study di Program Studi Pendidikan Matematika FKIP Universitas Veteran Bangun Nusnatara Sukoharjo, Prossiding Seminar Hasil Penelitian dan Pengabdian kepada Masyarakat LPPM Univet Bantara Sukoharjo.

Obara, S., \& Bikai, N. (2019). Promoting math teacher active learning with the lesson study approach A case study of in-service. https://doi.org/10.1108/IJLLS-11-2018-0088

Sapawardi, Lalu. 2015. Peningkatan Kualitas Pembelajaran Kalkulus Integral Melalui Kegiatan Lesson Study di Program Studi Pendidikan Matematika. Jurnal Pendidikan Matematika, 9(1), 35-48.

Vitantri, C.A. (2014). Penerapan Lesson study pada Mahasiswa Program Studi Pendidikan Matematika Mata Kuliah Advanced Calculus. Gamatika. Vol 5 Nomor 1.

Wood, P., \& Cajkler, W. (2016). A participatory approach to Lesson study in higher education. International Journal for Lesson and Learning Studies, 5(1), 4-18. https://doi.org/10.1108/IJLLS-08-2015-0027 